\title{
Illiberal Communication and Election Intervention during the Refugee Crisis in Germany
}

\author{
Ashrakat Elshehawy, Konstantin Gavras, Nikolay Marinov, Federico Nanni and Harald Schoen
}

\begin{abstract}
Populist discourse - which tends to benefit anti-systemic parties - has been on the rise in the world's democratic states. Powerful non-democratic states have both the means and the incentive to spread such discourse to democratic states. We clarify the incentives illiberal states have to produce such communication, and delineate how this type of political communication fuses traditional stateto-state propaganda with election interventions. We draw on the case of Kremlin-sponsored communication on the issue of refugees in Germany to illustrate the mechanisms through which the discourse operates in target countries. We create a corpus of over a million news stories to identify the prevalence of illiberal discourse and its timing relative to Germany's elections. We show that the Kremlin intervened in the 2017 federal elections by promoting refugee stories over and above the rate at which German outlets did. We discuss the broader implications for the use of directed political communication as a form of election intervention.
\end{abstract}

$\square$ uring the German refugee crisis, Willy Wimmer, member of the German Christian Democratic Party, predicted that "this is the end of the Chancellorship of Angela Merkel." Russian Channel RT, operating in German, publicized his views, alongside other articles, declaring that the Chancellor is an "autocratic" leader who turned her own party into a political graveyard,

A list of permanent links to Supplemental Materials provided by the authors precedes the References section.

Data replication sets are available in Harvard Dataverse at: https://doi.org/10.7910/DVN/T2FZK3

Ashrakat Elshehawy (1) is a PhD Student at the University of Oxford (ashrakat.elshehawy@politics.ox.ac.uk).

Konstantin Gavras (1) is a PhD Student at the University of Mannheim(kgavras@mail.uni-mannheim.de).

Nikolay Marinov (1) is Associate Professor of Political Science at the University of Houston (nmarinov@uh.edu).

Federico Nanni is a Researcher at the Alan Turing Institute (nanni.federico@gmail.com).

Harald Schoen is Professor of Political Science at the University of Mannheim (harald.schoen@uni-mannheim.de). and that "Merkel is breaking German law and endangering the country" with her decisions on refugees. Chancellor Merkel had been a staunch supporter of post-Crimea sanctions against the Kremlin: RT coverage seemed like a payback. The use of directed political communication by foreign actors to sway the politics of a country, especially close to elections, appears to be easier and more prevalent than ever. In this article, we study the general phenomenon and we look more in depth at the case of Germany during the "refugee invasion," to borrow a term from RT.

We identify the type of political communication produced by a particular class of regimes, delineate the likely targeted beneficiaries, and demonstrate its occurrence in an important case, the refugee crisis in Germany. The refugee crisis was exploited by the right-wing populist, partly extremist, and even anti-systemic Alternative for Germany (AfD) party. The refugee issue distinguished AfD's political communication from that of Germany's mainstream political parties, who were more positive on the new arrivals than the AfD. We show the latter with an analysis of party communications. We also show-by analyzing nearly one million news articles- that Kremlindirected outlets operating in German were markedly more negative on the issue of refugees than German media, and exhibited a greater conspiratorial bias. Among others, these outlets focus on portraying German chancellor Merkel negatively, linking failures in the refugee crises with her directly, splitting the governing parties by 
inviting intra-party critics to interviews and aiming to keep the refugee issue on the agenda for years after the immediate crisis. ${ }^{2}$ Especially after the federal election of 2017 , these outlets emphasize the AfD being the winner of the election, heavily criticizing the "mainstream" parties and chancellor Merkel. ${ }^{3}$ Thus, Kremlin-sponsored media provided what AfD operatives may have found useful-a news forum publishing appropriately slanted migrant stories, to refer to in political discussions. We find evidence that Kremlin-supplied coverage spiked, compared to domestic outlets, around the national elections that also resulted in AfD's most significant political breakthrough. The success of the AfD benefited the political agenda of the intervener, by making coalition-building among established parties more difficult. The anti-refugee message more broadly exacerbated internal divisions in the ruling parties and may have dissuaded voters from turning out.

In foreign election interventions, often what is most difficult to show is that attempts to sway the election are, in fact, being made (Brutger, Chaudoin, and Kagan 2021). Senders of interventions often deny or fail to acknowledge that their actions can be construed as that: China manipulated retaliatory tariffs in a manner that hurt the Republican Party (Kim and Margalit 2021). Foreign governments can argue that the discourse promoted through propaganda efforts has no obvious political beneficiary, and in any event, it is not intended as election intervention. By obtaining a large corpus of different news media materials over time-and political parties' communications - we show that foreign communication was systematically different from domestic media, that it was aligned politically (thematically) with a specific party, and that coverage spiked close to elections, again relative to domestic news channels. In tracing the existence and mechanism of intervention, our contribution is to provide a set of tools-conceptual and methodological - to identify how directed political communication turns into an election intervention. Thus, we take a step that is a necessary condition to study the wider prevalence of the phenomenon of political communication as election intervention.

The methodology we have employed in this work is borrowed from the field of computer sciences, it relies on tools developed in the field of natural language processing (NLP) and their adaptation to the political science domain. This interdisciplinary area of research allows modeling of complex phenomena, such as the one discussed in this paper. It helps researchers process large-scale amounts of textual data and to employ automated methods to analyze those massive amounts of text. ${ }^{4}$ Our identification of conspiratorial bias is novel: while it may not work for all cases, it may allow others to continue building tools on how to detect such discourse in large text corpora. Our methods - and the corpus we provide - may help scholars study the emerging links between populist movements and groups in democracies, foreign governments, and political movements.

\section{Illiberal Political Communication as Election Intervention}

Government capacity to generate directed political communication, aimed at foreign publics, represent ways of building up "soft power" in Nye's term (Nye 1984). Soft power is the ability of a state to get another state to act in accordance with the first state's wishes, which can be accomplished by swaying public opinion in a positive direction (Goldsmith and Horiuchi 2009), or by influencing specific elites (Machain 2021). ${ }^{5}$ Political communication is often a key part of "hybrid war" operations (Johnson 2018), a term used to describe measures as diverse as engineering scandals about politicians or launching cyber-attacks on infrastructure.

We use the term government foreign propaganda to refer to any sustained, mass communication to a large audience under the control of a government actor (Lasswell 1938) that is used with a political objective. It can originate in any regime type: democracy, autocracy, or regimes in between. State-to-state propaganda operations may have a well-defined specific objective (e.g., victory during war), or more diffuse on-going goals such as the promotion of an ideology, particular views on foreign policy issues, or the general good image of the sender. ${ }^{6}$ Under the umbrella term propaganda, we group a variety of different information formats, as we detail shortly.

Regimes with sufficient resources have also tended to direct political communication externally. This includes great and regional powers. All five states holding permanent seats in the United Nations Security Council have broadcasting operations aimed at publics abroad. Soviet propaganda included the government-owned Pravda newspapers and various channels of distribution of the message to external markets. ${ }^{7}$ In the Cold War period, partly in response to Soviet efforts, the United States set up radio programs and other news outlets to publicize the merits of a free society (Cull 2008). British and French news operations abroad are especially strong in former colonies. ${ }^{8}$ Chinese news and radio agencies started as a regional operation and now include a global market. ${ }^{9}$

We focus on externally directed, illiberal propaganda of non-democratic regimes. Illiberal propaganda originates as a general domestic pro-regime narrative. It features tropes of overzealous, out-of-touch liberal elites, together with political conspiracies about a corrupt "deep" system, promotes policy paralysis and withdrawal. Promoting identity politics and real or imagined threats increases acceptance of more authoritarian tendencies (e.g., Hetherington and Weiler 2009). Fanning political conspiracy theories reinforces a sense of threat, boosting support for strongman rule. Conspiracy theories render all information 
suspect, disorienting domestic publics further and defanging political scandals. ${ }^{10}$ By weakening regime critics, and thinning the ranks of their followers, such political communication helps the survival of illiberal regimes (Svolik 2013).

The phenomenon we study straddles state-to-state propaganda and election interventions. We know that all powerful states generate directed political communication abroad: the Voice of America was briefly deemed irrelevant with the end of the Cold War but is now back with a vengeance and in more languages than ever (Cull 2008). This type of communication is designed to achieve various desirable goals, such as a better image of the sender state, the promotion of specific ideas, and values. We also know that outsiders, particularly great powers, intervene regularly in the elections of other countries to assure the election of congruent candidates and parties (Bubeck and Marinov 2019). The 2016 U.S. election of Donald Trump has brought this issue home for the American public. One of our contributions is to relate the two. Regimes produce externally oriented political communication, whichwhen the conditions for engaging in election interventions obtain - turns into an element of a strategy of influence, targeting election outcomes.

Under certain conditions used against election-holding states, state-to-state propaganda may form a part of a strategy of election intervention. A growing research agenda on election interventions documents their impact on public opinion in target states (Corstange and Marinov 2012; Shulman and Bloom 2012; Tomz and Weeks 2020), and on election outcomes (Levin 2016). Election interventions are part of foreign meddling in democracy and may impact attitudes toward cooperation with the sending state (Bush and Prather 2020).

We know that election interventions are relatively common, with one in three elections experiencing some form of external meddling (Bubeck and Marinov 2019). Interventions can be of two kinds: democracy-promoting (eroding) ones (Hyde 2011; von Borzyskowski 2019), and support for specific partisan tickets (Levin 2016). Partisan interventions are government-backed attempts to increase the support specific parties or candidates receive at the ballot box. Candidate, or partisan, interventions may involve the tying of foreign aid to the performance of a certain ticket, attempts to aid a political campaign with resources or other means. Such support can be overt or covert, and may or may not involve extensive collaboration between the foreign power and supported actors. There is a great variety of candidate-oriented partisan interventions. About one-third involve help with party campaigning - which may include the production of political communication (Bubeck and Marinov 2019). There is no systematic data, indicating the prevalence of directed political communication as a strategy of election intervention. If the alignment between U.S. channels of communication such as Voice of America and right-wing parties and candidates, on the one hand, and between TASS communiques is any guide, such practices may have occurred frequently.

Foreign powers may not find a domestic political movement that is ideologically congruent and politically viable. In that case, "marriages-of-convenience" can take shape. For example, Soviet interventions in the Cold War often took the form of direct endorsements; the Soviets directly asked Germans to vote not for Chancellor Kohl, but for the Social Democrats in the 1983 election. ${ }^{11}$ Or, even more prosaically, a document would be anonymously leaked with damaging information on a candidate. ${ }^{12}$ Overall, the ideological narrative of Communist propaganda favored leftist parties but this could take a back seat, according to the situation. It is thus little wonder that after decades of a pro-left narrative during the Cold War, in the last two decades the anti-systemic narrative has been more nationalist and populist (Pomerantsev and Weiss 2014). From a non-democracy's point of view, when the political landscape in a targeted country features a viable populist or anti-systemic party, amplifying illiberal propaganda targeting democratic voters would be a natural means of helping an actual or potential ally at the polls.

The type of domestic political discourse produced by illiberal regimes is close to the agenda of populist and antisystemic parties (Rooduijn and Pauwels 2011)—which aim to undermine the legitimacy of the existing regime (Sartori 1976, 132-3). Populist actors primarily build on the idea that society is ultimately separated into two homogeneous and antagonistic groups, "the pure people" versus "the corrupt elite," and argue that politics should be an expression of the will of the people (volonté générale; Mudde 2004). Accordingly, they challenge the political establishment, attempt to undermine its credibility, and claim to give ordinary people a voice in politics in their country (Mudde 2007; Moffitt 2016). It has also been noticed that in pursuing their goals, these politicians accuse their opponents of elite conspiracies and propagate conspiracy theories (Albertazzi and McDonnell 2008; Hawkins 2009). These goals and ideas have some overlap with illiberal regime politics that is intended to weaken liberal-democratic governments in the international arena. As populism builds on a unitary notion of the people who are opposed to an evil elite (Mudde 2004), narratives that, for example, challenge minority rights, criticize elites, or claim elite conspiracies against ordinary citizens may help populist parties at the polls. In turn, increased electoral support for them may make it more difficult to form stable governments that demonstrate the strength of democracy and take a clear stance on non-democratic regimes in the international arena.

We focus our attention on an important case in terms of the target of interventions, that of Germany, looking at the discourse surrounding the refugee crisis. We do not seek to 
appraise how common intervention through propaganda is, or to demonstrate that illiberal regimes systematically support populist movements now. Our goal is more modest. We attempt to explore whether political communication originating in an illiberal regime-Russia-complied with the logic of our argument. It promoted issues that aligned most with a populist party, and communication spiked close to national elections-in a manner consistent with an election intervention. We show, furthermore, that agreement between foreign and domestic illiberal communication consisted of adopting a similar tone on an issue (such as a negative one toward refugees) and of adopting a conspiratorial perspective on the issue.

\section{Illiberal Political Communication during the Refugee Crisis in Germany}

Russia is one of the most powerful illiberal regimes in existence, and is a good test case for some of the propositions we develop. Many of the strategies developed by the Kremlin were first tested domestically (Sanovich, Stukal, and Tucker 2021) and then deployed in the West as retribution for Western "meddling" in its own elections (Robertson 2017). The Kremlin was an early adopter of online tools for spreading pro-regime propaganda (Gunitsky 2015). The creation of the government-sponsored Russia Today offers a target of opportunity. It is an important bellwether, well linked to the regime (Elswah and Howard 2020). Table 1 illustrates the reach and scope of Russia Today (RT). There are other operations, such as Sputnik; those are more internally oriented, though over time they have also acquired an international arm.

The refugee crisis in Germany has been dramatic, with more than 2.3 million unauthorized crossings into Europe between 2015 and 2017 alone. $^{13}$ The largest share of approved applications for refugee status were granted by Germany (Slominski and Trauner 2018). The crossings started an intense debate, between "refugees are welcome" and "migrants go home" (Arlt and Wolling 2017), challenging the traditional left-right political establishment (Mader and Schoen 2019).

For a long time, Germany has been considered an outlier when it comes to electorally successful far-right parties (Dolezal 2008; Bornschier 2012). Things changed with the advent of the "Alternative für Deutschland" (AfD). Initially founded in early 2013, it primarily voiced opposition to the European Monetary Union and the politics of rescue packages (Arzheimer 2015; Grimm 2015) and almost entered the German Parliament in that year. When the influx of large numbers of refugees set in in 2015 , however, the party shifted its focus to opposition to immigration and the intake of refugees (Arzheimer and Berning 2019). With its populist approach, the AfD complemented the Left Party (Die Linke) which is considered by many observers a left-wing populist party (Rooduijn et al. 2019). ${ }^{14}$ Depending on the nature of the political agenda, this party may benefit from illiberal propaganda, for example, in cases of economic crises. During the refugee crisis, however, the AfD made a successful attempt at attracting support from critics of the official policy—backed by all mainstream parties, whereas the Left Party did not.

The electoral surge of the AfD took place during the crisis, in a step-wise fashion. Its first electoral breakthroughs were in state (Land) elections, which predated the entry into Parliament with the federal election of 2017. In the state elections held in early 2016, the AfD garnered roughly $13 \%$ to $15 \%$ in West German states and not less than $24 \%$ in Saxony-Anhalt. Later in that year, the party also entered the state parliaments of Berlin and Mecklenburg-Western Pomerania by getting $14 \%$ and $21 \%$ of the votes respectively. In the remaining state elections held before the 2017 federal elections, the AfD also got parliamentary representation, though the level of electoral support was somewhat lower. In these elections, critics of the intake of asylum-seekers and more broadly of immigration were disproportionately likely to cast votes for the AfD (Arzheimer and Berning 2019; Mader and Schoen 2019). It is thus little wonder that the refugee crisis was characterized as a "present" for AfD by top party leaders. ${ }^{15}$

The refugee issue provides fertile ground for the development of illiberal propaganda. "Subverting culture," identity politics, and feckless liberal elites are core tropes in such discourse. ${ }^{16}$ In what follows, we test a "spin" proposition (official Russian channels are less likely to push outright lies than online bots), and an "election intervention"/"salience" proposition. The first is a test of whether a specific policy issue distinguished a specific

\section{Table 1}

RT operations in different languages

\begin{tabular}{lcccc}
\hline & Facebook Likes/Followers & Twitter Followers & YouTube Subscriptions & Instagram Followers \\
\hline RT Russian & $2 \mathrm{M} / 2 \mathrm{M}$ & $864.7 \mathrm{k}$ & $1.38 \mathrm{M}$ & $320 \mathrm{k}$ \\
RT English & $5.7 \mathrm{M} / 6 \mathrm{M}$ & $3 \mathrm{M}$ & $3.84 \mathrm{M}$ & $569 \mathrm{k}$ \\
RT German & $436 \mathrm{k} / 471 \mathrm{k}$ & $48.2 \mathrm{k}$ & $347 \mathrm{k}$ & $35.5 \mathrm{k}$ \\
RT French & $1.1 \mathrm{M} / 1.3 \mathrm{M}$ & $155.6 \mathrm{k}$ & $651 \mathrm{k}$ & $69.8 \mathrm{k}$ \\
RT Spanish & $11 \mathrm{M} / 12 \mathrm{M}$ & $3.4 \mathrm{M}$ & $3.57 \mathrm{M}$ & $757 \mathrm{k}$ \\
RT Arabic & $15 \mathrm{M} / 16 \mathrm{M}$ & $5 \mathrm{M}$ & $4.12 \mathrm{M}$ & $1.2 \mathrm{M}$ \\
\hline
\end{tabular}


party, and whether foreigners promoted this issue in a manner aligned with and potentially beneficial to that party. The second checks whether foreign sources amplified coverage of the issue (more than domestic sources) close to pivotal targeted elections.

We have argued that the rise of anti-systemic parties generally destabilizes democratic opponents. In the case of the AfD and Russia, Russian interests have been promoted more directly by the party. Members of the AfD have openly promoted reaching out to Russia and trying to fundamentally shift foreign politics in Germany (Wood 2020). The ongoing conflict between the moderate and more extreme wings of AfD was decided in July 2015 with a victory for the extreme wing. The winning side was comprised of members who were more hostile to refugees and more firmly in support of the party line of abolishing sanctions on Russia. The victory of the extreme wing possibly contributed to the big electoral breakthroughs in the 2016 state and in the 2017 Bundestag election (Jäger 2021, 7-8). These electoral gains were strongly supported by Russian-German resettlers, usually supporting the CDU and CSU, but decided to switch away when the AfD was more openly holding pro-Russian positions (Goerres, Mayer, and Spies 2020). Additionally, this societal group is also more likely to consume Kremlinsponsored media, making them more vulnerable to misinformation campaigns (Golova 2020). Along with support for Russia in annexation of Crimea and the military aggression in Donbass, the AfD tries to narrate a more positive picture of Russia in German political communication, putting the blame for political and military aggression on the side of the United States of America, NATO, and the German federal government (Wood 2020). Ties to the AfD may have provided the Kremlin with "trickle down soft power" (Fisher 2021). We would, therefore, expect political communication to be also used as a tool of election intervention. To clarify: per our argument, an outlet such as RT pursues partly political objectives with refugee coverage, and these objectives increase in value (salience close to elections). Russian sources also pursue other objectives (which is why they do not only talk about refugees), but the value of these objectives becomes secondary in targeted election periods.

The following concepts are relevant in any issue of political communication: salience, spin and misinformation. We want to know what spin Kremlin sources put on the issue of refugees. This includes whether the issue was presented in a positive or negative light, and whether the existence of conspiracy was insinuated or suggested. The reason we focus more on the conspiratorial aspect of stories than any other specific negative theme in the coverage is because the conspiratorial angle may be an important and somewhat overlooked aspect of political competition. In Eastern Europe, it may allow governing parties to effectively hide state capture by appealing to voters with authoritarian tendencies, while shifting criticism to (allegedly) refugee-cuddling reformist oppositions (Marinov and Popova 2021). ${ }^{17}$ These types of voters may be especially likely to turn against the mainstream. We also check whether coverage of refugees became more salient at certain points. We cover the angle related to misinformation-patently false stories- the least. We are unable to evaluate the factual basis of the narratives. We note, however, that even if semi-official Russian sources (unlike bots) refrained from peddling obvious untruths, a certain amount of spin and suggestions may be equally effective in leading public opinion in the intended direction.

\section{Party Communication}

Here, we test to what extent the Kremlin (Russian outlets, operating in German), distinguished themselves from German news sources, by being more negative on the issue of refugees. We also check whether the AfD's official political communication on the issue of refugees distinguished them from other parties, by being more negative, and whether the AfD and the Kremlin spread conspiracy narratives in a manner that set them apart from other actors.

Proposition 1: The AfD is more likely to be negative on the issue of refugees than other parties, and Kremlin sources are more likely to align with AfD political communication on refugees, measured by negative and conspiratorial sentiment, compared to domestic sources of mass communication.

Party communication: The AfD and other parties on refugees. Press releases are an important tool of party political communication, used by parties to influence public political discourse. As such, they are intended to influence how the media reports about political issues, building a public narrative that follows the party's frame of the issue. Press releases typically cover only one specific topic and frame the party's position in a way that is clearly communicated. Furthermore, press releases differ by government and opposition, with governmental parties trying to highlight their successes and opposition parties shedding light on potential failures and shortcomings of government policies (Froehlich and Rüdiger 2006).

Sentiment in party communication. We captured the press releases of Germany's main parties, and classified the refugee-relevant ones. Our procedure for downloading the communications was to identify the homepages where the political parties stored their press releases. We scraped press releases for all parties currently represented in the Bundestag: CDU/CSU, SPD, Greens, FDP, the Left Party, and the AfD. We classified the first four parties as nonpopulist, mainstream parties, and the latter two as nonmainstream, populist parties for the remaining analysis (Rooduijn et al. 2019). We decided to gather the press releases of the parliamentary groups for the mainstream 
parties and the Left Party, since these parties often did not regularly publish press releases from their party platforms. ${ }^{18}$

We scraped the content from the homepages. We used both classical web-scraping and JSON-extraction. Next, we used natural language processing (NLP) techniques to find stories that are semantically related to our dictionary (in the online appendix, A.1) that includes a set of terms describing the topic under study: refugee stories. Essentially, we need to see which releases are about refugees. A human would do this easily, for a small number of stories. We have a lot of data, and so we rely on automatic methods while using humans to validate or check the quality of the output on a small subset of the articles. One basic automated approach is to use keywords: humans define the encounter of what keywords in an article would make it "about refugees." Another approach uses word-embeddings or "the company words keep"-a type of numerical representation of words that permits words with similar meaning to have a similar representation. If an article has words that are close to refugees, as observed in a very large corpus of data, it is labelled as refugee-relevant. ${ }^{19}$ We rely on both the key-words based technique and word embeddings. ${ }^{20}$

After retrieving only the refugee-relevant texts, we take a look at the press releases by party. We note that the AfD devotes far more of its attention to the refugee topic than other parties: nearly one-quarter of its releases deal with the topic, as compared to $6 \%-7 \%$ for the governing parties (figure 4 in the online appendix). Thus, this is a salient issue for them.

Next, we perform a sentiment analysis on the resulting text dataset of refugee-related press releases. We simply count the number of occurrences of positive words and negative words in each month of our corpus and calculate the proportion of positive words in the total number. ${ }^{21}$ We note that the resulting proportion should not be interpreted relative to some abstract and absolute notion of positive; a sentiment score of 0.55 is more than half positive words but a human may perceive that the article is quite negative overall. Rather, we claim that a higher score means more positive coverage, but whether that means truly positive or simply less negative is a different issue. ${ }^{22}$ Validation of the scores by humans is a common way to establish that sentiment analysis measures what the researcher wants, and to anchor what negative and positive truly mean. This also helps position in perspective and correctly evaluate the size of the observed differences. We had human coders rate independently a random sample of 150 political texts in positive, negative, and neutral terms, as far as sentiment toward refugees is concerned. Figure 8 in the online appendix, party panel, shows that small changes in sentiment score map into large differences in human judgement. Essentially, stories below 0.65 are negative according to humans, and stories above this number are positive. ${ }^{23}$
With that in mind, we compare the parties' scores on figure 1 by month. AfD has a lower proportion of positive words than the other parties, a result which is statistically significant in a two-way difference-of-means t-test. For the test, we aggregate all mainstream parties and contrast them with the sentiment scores of the AfD over the whole time span. The average proportion of positive words is at about 0.59 for the AfD, for the mainstream parties it amounts to 0.64 with a statistically significant difference $(t=5.58)$. Despite some variation over time, the AfD was more critical in their press releases than mainstream parties.

We further note that populist parties can be on the left and on the right; our argument does not specify exactly which party would benefit from foreign communication. In the case of Germany, die Linke championed refugees (as being hurt by a global capitalist system), and painted the enemy group in radically different terms from the AfD. Electorally, attacking refugees has been the winning issue politically in Europe, and that may have affected the direction of the Kremlin's coverage.

Conspiratorial bias in party communication. Parties in Germany do not pander conspiracy theories overtly in terms of remarks officially printed in, say, party positions. When we broaden the look beyond official communications, we note that whereas German mainstream parties refrain from employing conspiratorial language in any channel, the AfD does have a history of pandering conspiracy theories in certain types of media. The AfD is particularly active in Twitter and on YouTube where they are able to directly communicate with their supporters. Furthermore, board members of the AfD give interviews to right-wing newspapers and broadcasters, which deem themselves as an alternative to "mainstream media." Conspiracy theories are also triggered in speeches of board members to party members in closed or semi-public party meetings. In each of these communication channels, members of the AfD refer to conspiracy theories even though it might not be part of their official political communication.

During and after the refugee crisis, references to conspiratorial theories have been widespread in some parts of society (Molz and Stiller 2019). Especially in right-wing audiences, theories on ethnic inversion ("Umvolkung") were prevalent. This narrative shows up for decades in the extreme right but never has been made so public as during the refugee crisis (Harris 2001; Rosellini 2020). On Twitter, Beatrix von Storch, an AfD board member, is known for spreading the ethnic inversion conspiracy frequently to frame the opening of the borders for refugees as a plan for replacing the white German population by immigrants from African and Arab countries. ${ }^{24}$ On YouTube, similar references can be found in videos, which were produced by the AfD broadcaster (AfD-TV) during the discussion on the Global Compact for Migration. ${ }^{25}$ 


\section{Figure 1}

\section{Sentiment analysis: AfD versus Mainstream parties combined on refugees}
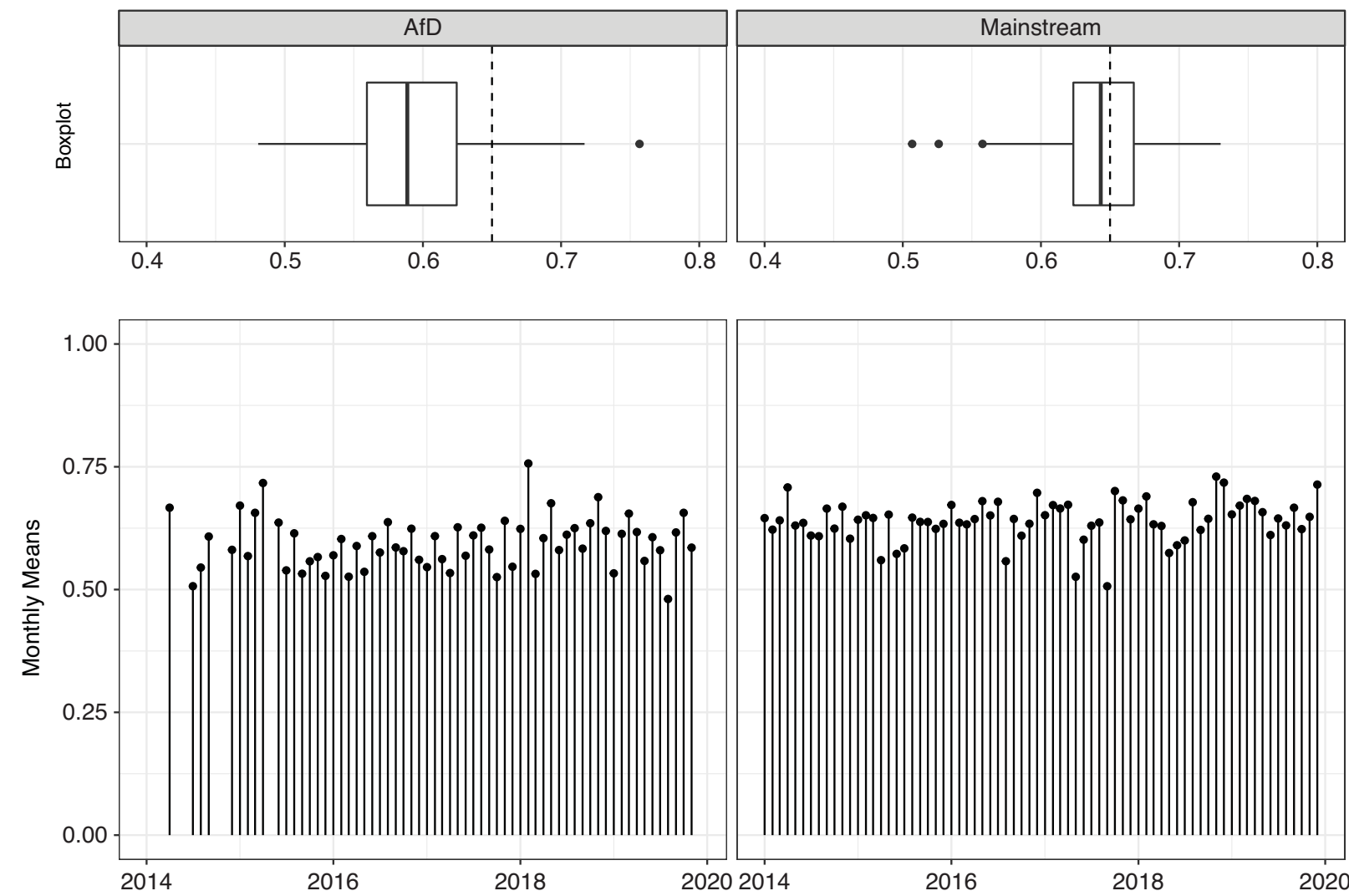

Note: Proportion positive words (positive over positive+negative over month). Dashed line shows lower bound of what humans consider a positive story. Based on 1,265 total number of documents.

When giving interviews with right-wing newspapers and broadcasters, AfD members often change their lingo very significantly compared to their official political communication. When giving interviews to Compact and PI (Politically Incorrect), we find clear references to conspiracies in general and on ethnic inversion in particular. ${ }^{26}$ Politicians of the AfD are even willing to pick up these conspiracies in their speeches, however, being more careful about the terms used in order to prevent observation by internal intelligence authorities. Björn Höcke uses the yearly meeting of the far right-wing part of the AfD to refer to several conspiracy theories, including both ethnic inversion and plots of the government with other nations. ${ }^{27}$ Finally, there is evidence that the floor leader of the AfD, Alexander Gauland, also referred to this conspiracy when speaking in the plenary debate of the Bundestag, ${ }^{28}$ making the conspiratorial bias of the AfD very visible for a broader audience.

\section{Mass Communication}

Next, we want to appraise the role of foreign and domestic sources of communication on refugees. We focus on two
Kremlin media channels broadcasting online in German: Sputnik.de and RT Deutsch (Spahn 2018). Sputnik.de and RT Deutsch began operations at an opportune time-in the middle of November 2014, just as the number of asylum-seekers arriving in Europe started to tick up. Sputnik is a more voluminous operation, one that extended and rebranded abroad an existing domestic Russian service. Russia Today was specifically created for the Western media market. Given this original intention, we would expect to see that RT is more attuned to strategic goals in this case, namely, to feature more negative coverage, more conspiracies, and to depend more on the election calendar.

The case of a young girl ("Lisa") went missing for a few days in Berlin exemplifies this strategy very well. In January 2016, a young girl was announced missing by her German-Russian parents. When she re-appeared a few days later, she argued that she had been kidnapped and raped by some "southern-looking" men. Although during police interviews it became quickly clear that the girl made up the story, Russian media-RT Deutsch among others - reported intensively on this case. Russian media spread 
conspiracies for weeks that refugees were responsible for committing the crimes against the young girl, arguing that the police were not willing to resolve crimes committed by refugees. ${ }^{29}$ Additionally, they accused German mainstream media to spark anti-Russian sentiments in the German public, aiming to reach their strategic goals of destabilizing mainstream political elites. ${ }^{30}$

Sentiment in mass communication. To put the coverage of the issue by the Russian sources into perspective, we compare it to the coverage by domestic sources. Specifically, we examine German media, including the Frankfurter Allgemeine Zeitung (FAZ_center-right, on the political spectrum), the Süddeutsche Zeitung (SZcenter-left), Welt (center-right), Tageszeitung (TAZ/left), and Bild (tabloid). We start by scraping the entire corpus of more than 700 thousand articles published by those outlets. ${ }^{31}$ Next, we use the same Natural Language Processing (NLP) techniques described earlier in reference to party political communication to retrieve only refugeerelevant stories from our corpus. ${ }^{32}$

This yields a total of 25,450 stories, for the period spanning the start of 2014 to the end of 2018 (broken down by news outlet in table 5). At the height of the crisis in the summer of 2016, there were some fifty refugeerelated stories across the different outlets daily, marking the topic's importance. There is a difference between the German and Russian outlets. Among the German ones, coverage ranges between $1 \%$ (Welt) and 10\% (FAZ), with the mode being $6 \%$ (TAZ). The Russian outlets range between 11\% (Sputnik) and 15\% (RT). Russian media broadcasting in Germany focuses more of their attention on the topic of refugees than the modal German outlet during the period under study, an observation which is consistent with the posited influence operation pursued by those outlets. The high interest in some German media in refugees should come as no surprise-the challenge of accommodating the refugees has been one of the most significant political challenges in the history of the Federal Republic.

We next run a sentiment analysis on the monthly aggregated content, using the same procedure as described in the party communication section. Figure 2 shows the positive-words ratio of the refugee-related stories, by month, of the German and Russian publications. Russian sources are more negative, a result highly significant in a difference-means test. We aggregate Russian and German outlets and test for differences in mean over the whole time span. The Russian sources show on average a proportion of 0.53 positive words, whereas the German outlets are considerably more positive with about 0.57 . The differences between the means is statistically significant on the $95 \%$ confidence level $(t=4.99)$. The online appendix section B.1 presents sentiment results by outlet. As expected, RT has the lowest score: when only considering RT, the average proportion of positive words drops to 0.49 . We should emphasize the importance of tailoring: Sputnik mostly re-translates Russian domestic propaganda, which was more focused on issues other than the Western European refugee crisis. While illiberal in nature, Russian domestic messaging may differ in emphasis from the most effective message from an external point of view. This encourages further thinking about how deflecting attention from domestic problems and intervening in foreign political discourses relate. ${ }^{33}$

We conduct a validation analysis on a random sample of 150 pieces of text in order to see how humans would rate stories classified as more or less positive by the automatic scoring. Small changes in the sentiment score map into large differences in human judgement. ${ }^{34}$ As human judgement turns more positive, so does the mean automated score. It turns out that stories with a score of 0.55 and above are positive, and stories with a sentiment score of less than 0.55 are perceived as negative.

Figure 9 shows breakdown by outlet. Russian outlets have significantly more negative coverage than all other outlets. In fact, they exceed significantly even Bild, a national tabloid. One may note that German mass media outlets feature a more negative words ratio than the AfD in its press releases. This may reflect differences in the nature of communication mediums. Official party political text likely follows conventions that are different from news media reporting. We note that human coders find different cut-off criteria for positive versus negative stories for the two types of communication, which is consistent with the idea of different communication styles being used ( 0.65 for the cut-off to negative for political communications related to parties and 0.55 for communication related to papers).

Conspiratorial bias in mass communication. We argue that promoting conspiracies plays into the hands of local actors in Germany, appealing to supporters of non-mainstream parties. We also argue that it links up the "threat" refugees pose to ways in which the Kremlin has been "wronged" (by pro-democracy movements, sanctions) and thus it advances the Kremlin's geo-political objectives by making everything connected in a single arc of evil.

Anecdotal evidence suggests the wide use of conspiratorial tropes by Russian sources. The theme of Muslim refugees "invading" the EU is an integral part of the "effeminization" of the West trope in Kremlin communication (Cushman and Avramov 2021).

On the issue of refugees, we attempt to identify the systematic conspiratorial bias in mass communication. We use NLP approaches to get deeper into the content of the articles and measure their relatedness to the topic of conspiracy. We generate a set of keywords for these topics based on our reading of a broad array of articles across outlets. These include general terms about secrets, hidden government documents, plots, "world leaders"-masters of geopolitical intrigue. ${ }^{35}$ 


\section{Figure 2}

Sentiment analysis: Russian media (Sputnik and RT) versus German (left, FAZ, TAZ, Welt, Bild, and SZ) on refugees.
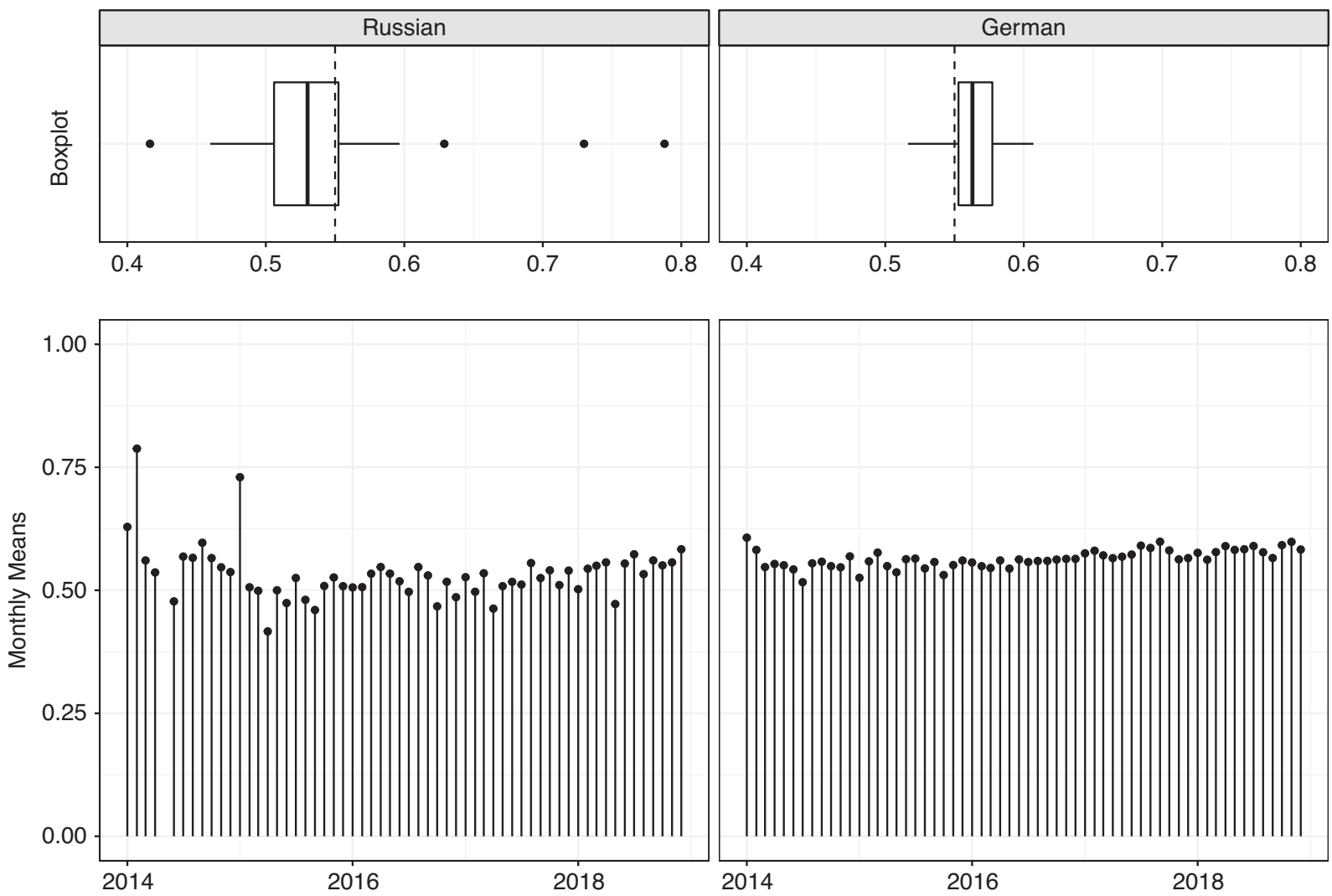

Note: Proportion positive words (positive over positive+negative over month). Dashed line shows lower bound of (what human coders consider) positive stories. Based on 25,450 total number of documents.

In the case of the Kremlin, conspiracy is often traced to George Soros, his Open Society foundation, and the color revolutions liberals are presumed to abet or even direct. ${ }^{36}$ We expect Kremlin sources to feature more of this language. Conspiracy-pandering not only presents the government in a bad light, but it also discredits the establishment more broadly and so plays into the hands of the AfD.

Conveniently, it creates a link to other issue-areas, in which the Russian government wants to sway public opinion. Thus, if Open Society and Western elites are the same actors who brought in refugees and who staged the Maidan protests in Ukraine, then all their actions, including democracy-promotion and the sanctions against Moscow, are illegitimate.

Figure 3 shows a density plot comparison in regard of the use of conspiratorial language between the two Kremlin newspaper sources and the five German ones, for all refugee-relevant stories in the period under study. The red
Figure 3

Conspiracy language

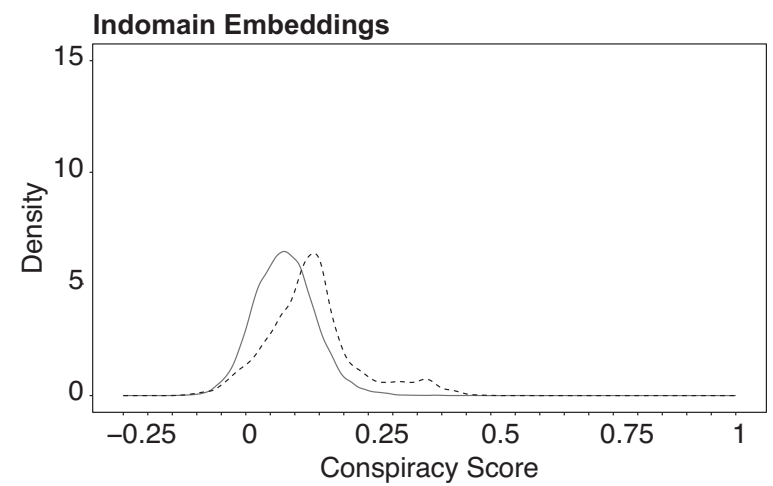

Note: Russian/German media - broken/solid line 
line represents the density of German media and the dotted black line illustrates the same for Russian media.

To create the conspiracy scores for Russian and German news, we compute a similarity score between each article's words and conspiracy-related topic words using two types of word-embeddings. ${ }^{37}$ Though there is no black-andwhite pattern, distinctions are visible. For conspiracy, the fiftieth percentile of similarity on Russian media coincides with the seventy-fifth on German media. ${ }^{38}$ A comparison of means test confirms that these differences pass conventional levels of statistical significance.

We conducted a validation check, to ensure that classification matches human judgement. ${ }^{39}$ When we take a closer look at the conspiratorial language within the Russian sources, we find that RT has a higher overall conspiracy score than Sputnik. Thus, conspiracy-pandering is especially valuable on democratic media markets.

We next conducted an ablation study by removing sequentially each word in our conspiracy-topic dictionary and re-calculating the produced results, to see which words increase similarity score in regard to conspiracy language the most. Figure 11 in online appendix D shows that Open Society, Euromaidan, and "interference" are among the most influential words driving conspiracy similarity. This confirms that one of the goals of pushing such stories may be to link domestic political debates in democracies to organizations and events that the Kremlin views as menacing, such as Western policy toward Russia and its neighborhood, while delegitimizing the welcome extended to refugees.

We should note that RT and Sputnik in German do not pander the most extreme versions of conspiracy theories. There are no accounts of lizards deciding world affairs. This may be due to norms of acceptable materials that they have to abide by or risk backlash in Germany. The channels hint and insinuate. An effeminate Europe on its knees is a complex figure that links up the fight for gender identity (and the myth of a liberal agenda gutting the West's strength) to an image of defeat by "religious infidels." This can be easily related to a more complex conspiracy out there (e.g., by Soros) but the dots are to be connected in the readers' imagination. We do not claim that we address the many fascinating complexities that come with conspiratorial narratives. We have merely taken a first step to flag such (related) discourse in a very large body of media publications and we hope future research can continue the analysis we start. ${ }^{40}$

\section{From Mass Communication to Election Intervention}

Here, we examine whether Kremlin-sponsored coverage increased closer to German elections, in particular close to the federal election of 2017, the election most likely to affect national policy.

Proposition 2: Kremlin sources will show disproportionate interest in refugees close to elections as compared to domestic mass media: with a spike especially likely for RT, and for the national elections.

To help visualize the data, we aggregated the daily stories and created a scatter plot by month in figure 5 . The figure also includes asylum registrations in Germany ('\# asyl reg' line), based on monthly data from Eurostat. ${ }^{41}$ The applicant numbers are not labeled but the lowest number10,175 - of asylum seekers is observed in February of 2014, and the highest number is recorded in August 2016 - 92,115 registrations. The graph carries dashed lines for state elections and with a solid line for the federal election in the period. There are a total of seventeen different polls, held on fourteen distinct dates (table 2).

We see that some German outlets devote more attention to the topic close to state elections taking place in the

\section{Figure 4 \\ Event study: Deviation of observed from expected daily refugee stories}

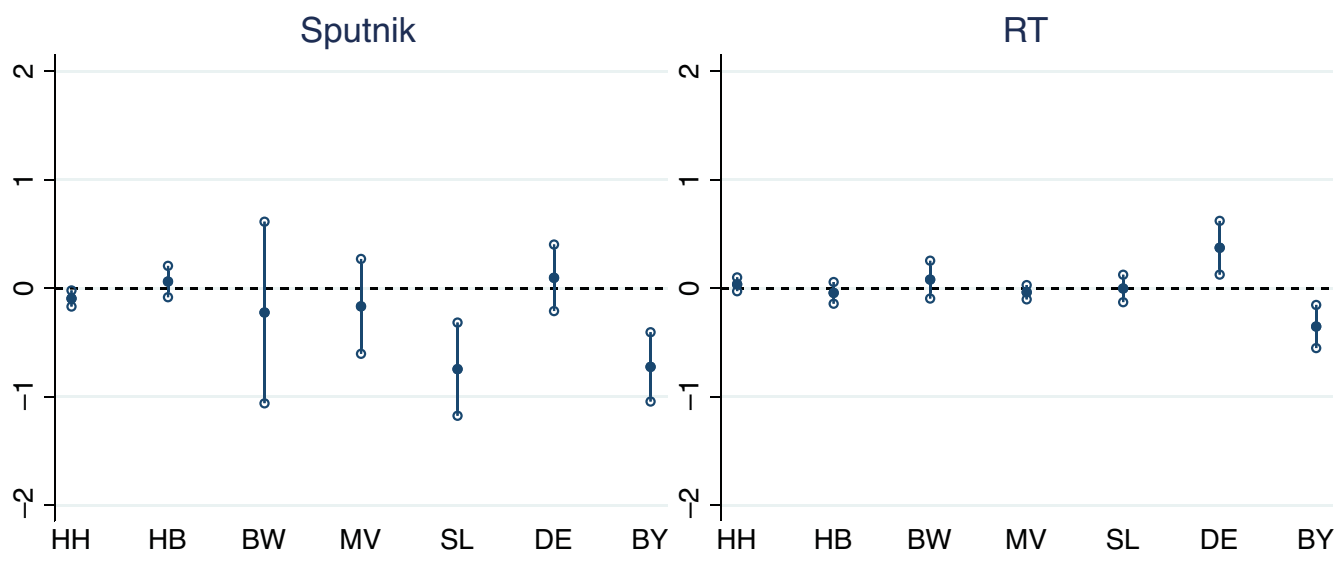

Note: $95 \%$ Cl. DE = Federal Election 


\section{Figure 5}

\section{Refugee stories by outlet, with elections}
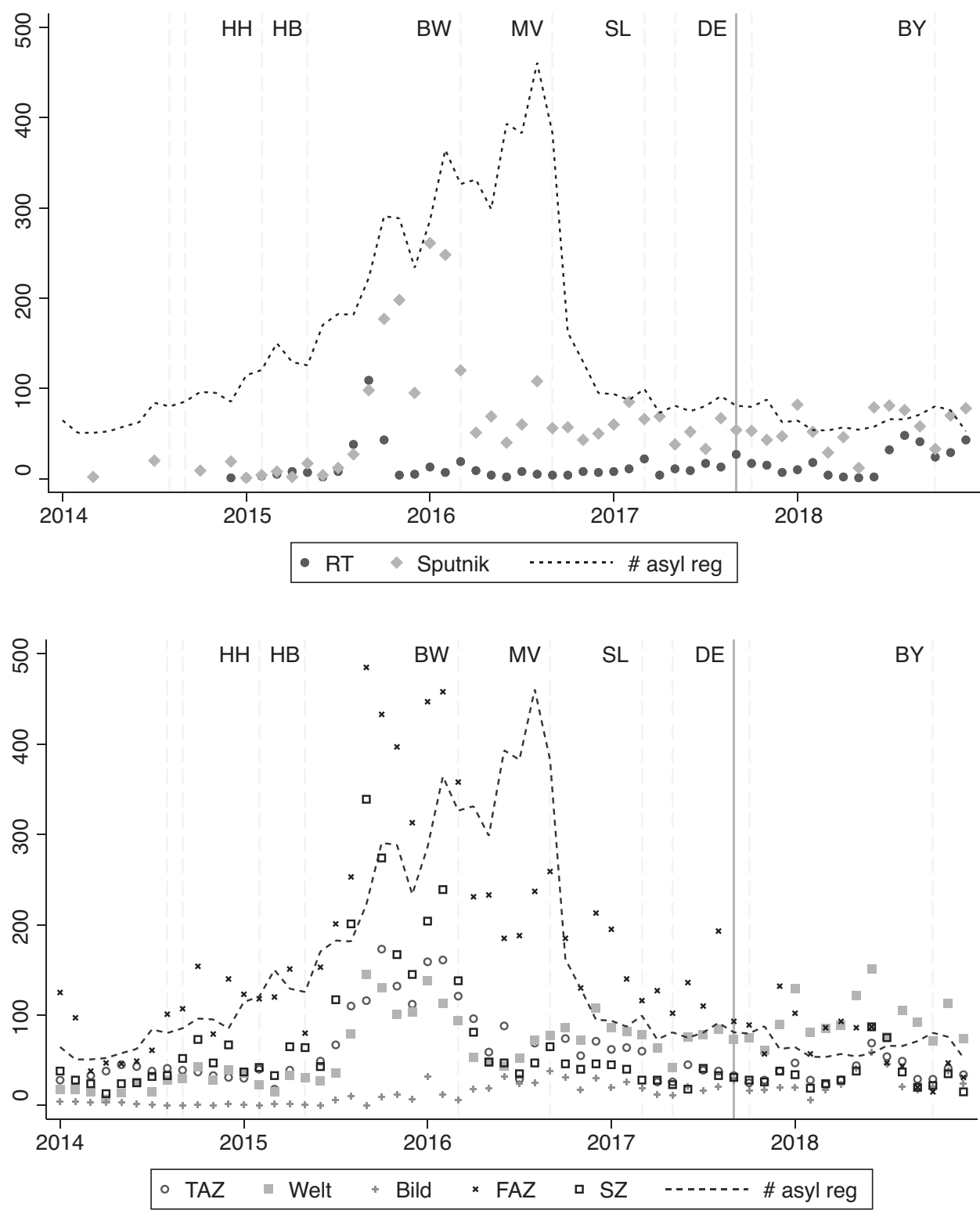

Note: Refugee stories by outlet (monthly), with elections (state/federal - broken/solid vertical lines). Asylum registration trend shown for comparison and not to scale.

months of March and September of 2016. This is the period of the highest number of refugee-registrations and of the British referendum on leaving the EU. Russian outlets share some of this tendency. Kremlin-affiliated media seems to devote disproportionate coverage close to the ensuing elections in March 2017 (Saarland) and in the federal election of September 2017.

A direct comparison would have the advantage of simplicity, but it cannot properly capture trends impacting all outlets at the same time in a similar manner. If high levels of arrivals, or some other variables, are driving interest in the refugee topic, we need some way of accounting for these factors. In addition, what we are truly interested in is comparing the relative spikes of electionrelated interest across publications. Do Kremlin-aligned media experience more/stronger spikes relative to German media?

We adopt an event-study estimation approach to answer this question. Frequently used in financial economics, this approach tries to establish whether some 
Table 2

German elections (land and federal)

\begin{tabular}{ll}
\hline Date & Locality \\
\hline August 31,2014 & Saxony (SN) \\
September 14, 2014 & Brandenburg (BB), Thuringia (TH) \\
February 15, 2015 & Hamburg (HH) \\
May 10, 2015 & Bremen (HB) \\
March 13, 2016 & Baden-Württemberg (BW), Rhineland-Pfalz (RP), Saxony-Anhalt (ST) \\
September 4, 2016 & Mecklenburg-Western Pomerania (MV) \\
September 18, 2016 & Berlin (BE) \\
March 26, 2017 & Saarland (SL) \\
May 7, 2017 & Schleswig-Holstein (SH) \\
May 14, 2017 & North Rhine-Westphalia (NW) \\
September 24, 2017 & Bundestag/Federal (DE) \\
October 15, 2017 & Lower Saxony (NI) \\
October 15, 2018 & Bavaria (BY) \\
October 28, 2018 & Hesse (HE) \\
\hline
\end{tabular}

events produce "abnormal" returns in the portfolios of some firms but not others (MacKinlay 1997). All stock returns are hypothesized to behave the same way, prior to some shock hitting some but not others, at which point their returns diverge: revealing that the shock has differential effects on a theoretically relevant subset. For example, when Suharto had an operation for a heart bypass, politically connected firms experienced a nose-dive reflective of the risk that political connections will lose value if the operation went awry. ${ }^{42}$ Other firms' returns did not budge in value nearly as much.

Key in those approaches is defining an estimation window and an event window. The estimation window helps determine each firm's expected stock return (at any time, leading up to and during the event). The idea is to use the estimation window outside of the event to develop a predictive model of returns, which is then applied to the event window: the difference between expectation and actual return provides evidence about whether or not expectations diverge significantly from what is observed. If yes, we conclude that the event is indeed a significant factor for abnormal (higher or lower) returns in the selected stocks. Formally, the model is summarized by Equations 1 and $2 .{ }^{43}$ We adjust the notation to our case. The average election-window effect (the divergence we are looking for) is defined as the average abnormal publication per day, a deviation calculated as a mean and confidence interval based on the difference between prediction and observation in the event window of daily stories on refugees.
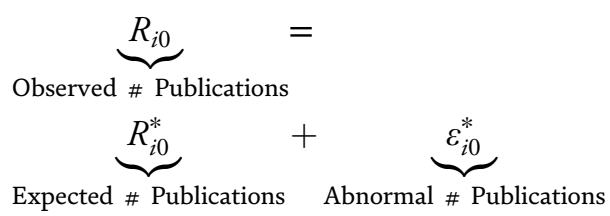

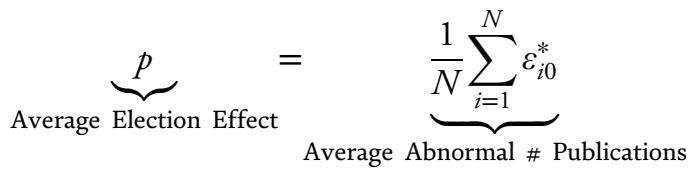

For the event window, we use the one-month period before and after an election (-30 to 30 days from the poll). This is our event $=1$ (shock) period. For the estimation window, we use the outlying one-month period in each direction: so the -60 to -30 days (period before the poll), and the 30 to 60 days (period after a poll). This is our nonevent, or event $=0$, period. In this period, underlying factors are most likely to be similar, and so this period should be most comparable to the election-proximate, event $=1$, period. ${ }^{44}$ We need at least several weeks before the election to capture the campaigning period. We also want to capture the period following elections, since the results are discussed, coalitions are formed and broken, and this, to us, is still a salient period for discussing political issues with a view toward damaging a political target.

The data, presented in table 2, presents some challenges. The two earliest elections fall outside of the period of operation of RT and Sputnik and cannot help identify the effects of election proximity on coverage. Of the remaining elections, some take place right after another: Lower Saxony held elections three weeks after the federal election. That poses issues with identifying the effects of election period: in October, if we are right, outlets should start responding to the end of the federal election period by decreasing coverage but the nearing state election may offset some of the expected decline. This would bias our test against finding an effect of the kind we are after.

To deal with that, we merge elections less than two months apart into a single event, defining the period between them as part of the election window (we still include the thirty days before the earliest election and the 
same period after the latest election in the event window). This affects, in particular, the Mecklenburg-Western Pomerania and Berlin Land elections; the Saarland, Schleswig-Holstein, and North Rhine-Westphalia ones; the Bundestag election and the Lower Saxony Land election; and the Bavaria and Hesse Land elections. Altogether, we have seven election events, labeled in figure 5 by the Land abbreviation of the (earliest, or first alphabetically) state holding a contest: 'HH' for Hamburg, 'SL' for Saarland and Schleswig-Holstein, and so on (we use 'DE' for the federal, Bundestag election)..$^{45}$ Our interest is to compare the number of stories within and outside of an event-window, for each of the seven election periods.

We use the estimation period to construct a model of how a particular news outlet publishes on refugees. To take the example of Sputnik, we fit an OLS model predicting Sputnik's interest in refugee publications as a function of all German outlets' interest during the same period and the number of asylum-seekers. We do the same for RT. Then, we use the fitted coefficients to estimate expected coverage in the election windows based on the same regressors. If this expectation deviates significantly from what we actually see, then we have "abnormal" coverage. Note that if German outlets are affected by the election, the approach should still work since we want to know whether Kremlin-aligned ones are affected lemph \{more\} (i.e., exhibit abnormally high coverage).

The results are shown in Figure 4. Standard errors and p-values are calculated using asymptotic t-statistics (MacKinlay 1997). ${ }^{46}$ There is no evidence of higher interest in elections close to Land contests; indeed, in some cases the two Russian sources covered refugees less heavily than German outlets. Things look different, when it comes to the federal election. RT Deutsch, but not Sputnik, publish 0.3 more stories per day in the month before and after the national (DE) election. Considering the daily average of 0.5 stories, this is a significant increase of $60 \%$. RT, set up specifically as a foreign broadcasting operation, again exhibits more "propagandistic opportunism." When it matters, the channel appears to broadcast more political communication on a topic favoring a locally aligned party —at rates exceeding domestic media interest in the policy issue. Salience increases with elections.

\section{Importance of Foreign Political Communication in the Elections}

Populist and anti-systemic parties, particularly on the right wing, have been on the rise in many democracies for at least a decade (e.g., Norris and Inglehart 2019; Rooduijn et al. 2019). A growing literature has identified a number of factors facilitating the success of these parties: large-scale processes of international economic cooperation, migration, and political integration that provoked public opposition that fueled support for these parties (Kriesi et al.
2006; Hooghe and Marks 2018). Others pointed to changes in the communication, in particular, the rise of the Internet and social media as a facilitator of the electoral success of elite-challenging, populist actors (Engesser et al. 2017; Schaub and Morisi 2020). We extend this debate by showing how information coming from abroad may have contributed to the success of populist parties in democracies.

We identify a strategy of election interventions that is novel and difficult to discern. Being a part of ongoing state-to-state communications operations, this type of intervention can only be identified through comparative analysis of trends relative to events and other sources of communication. We argue that illiberal regimes promote illiberal propaganda abroad, and that coverage should increase close to elections in democracies. Our case work suggests that Kremlin-controlled media promoted refugee stories, an issue beneficial to the populist far-right AfD party in Germany, in a manner more similar to the way the AfD approached the issue. Kremlin sources, and specifically the external propaganda outlet RT, promoted more negative sentiment and conspiratorial narratives-mainstays of AfD political communication. We also find that Kremlin-controlled outlets published more on the issue specifically close to the federal election, the contest that mattered most.

How might this coverage have helped the AfD? First, there is the direct reach of the channels which, according to our evidence, amounts to $6 \%-7 \%$ of Germans getting their news directly from the Kremlin outlets. ${ }^{47}$ Second, there is the indirect reach. RT and Sputnik are part of an ecology of entertainment channels, including Ruptly, InTheNow, and others. These would take content from RT and mix it to push out infotainment, without the source being necessarily recognizable (RT itself often uses nondescript acronyms such as RNA). We know that some of these outstrip German media in popularity. In addition, we know that much of RT's and Sputniknews's content is picked up on Twitter. Some Twitter hashtags become viral. ${ }^{48}$ The contents produced by RT and Sputnik get coverage of other media, thereby influencing public discourse-not least by making certain topics legitimate. This certainly happened in the "Lisa" case of a GermanRussian teenager allegedly abused by refugees, and it happens more broadly when results of public opinion surveys, commissioned by these Russian sources (or appearances of German politicians on RT or Sputniknews), attract attention in the media. ${ }^{49}$ Third, AfD party activists and leaders used the Russian channels in their political communications. A survey of party activists found that the RT Facebook page was the most liked information resource, preceded only by the Facebook pages of the party page and the page of the Pegida movement. ${ }^{50}$ Given that mainstream media shunned the topics promoted by the $\mathrm{AfD}$, access to an outlet with friendly political 
communication may have played an outsized role for mobilization purposes (Rone 2021).

What was the ultimate effect of this on the campaign in terms of views on refugees, support for AfD, voters cast? We lack an identification strategy to answer these questions at present. It has been demonstrated that negative framing of refugees influences mass attitudes: support for redistribution and integration diminishes (Avdagic and Savage 2020). We also refer to studies of political communication that demonstrate that consistent messaging has a non-trivial effect on party support and electoral outcomes (DellaVigna et al. 2014; Adena et al. 2015; Butler and De La O 2011; Crabtree and Kern 2018).

Whatever the relationship between media coverage of migration and the electoral performance of the AfD, ${ }^{51}$ the AfD's rise has had wider implications for German domestic politics. With increasing electoral gains of the AfD since 2014, German politics changed dramatically both on the regional and the federal level (Schmitt-Beck 2017). On the federal level, the surge of the AfD changed politics considerably. With almost 13\% vote share in the 2017 federal election and considered by all other parliamentary parties as not a potential coalition partner, the entrance of the AfD in the Bundestag prevented any two-party coalition despite the so-called "Grand Coalition," composed of CDU/CSU 52 and SPD, which was originally meant to be a coalition only to be formed in times of emergency (Bräuninger et al. 2019). After an attempt at forming a novel coalition comprised of CDU/CSU, the liberal FDP, and the Greens had failed, CDU/CSU and -grudgingly- SPD agreed to form yet another coalition government-after an unprecedentedly long process of government formation (Gärtner, Gavras, and Schoen 2020). This example nicely demonstrates the challenges the entry of the far-right AfD poses for electoral politics and governing in Germany.

What does our work suggest for other cases? We know that the Kremlin's combination of truths, half-truths, and plain lies forms a powerful information campaign, reaching many markets - in Europe, ${ }^{53}$ North America, and beyond. Ramsay and Robertshaw (2019) show how widespread the Russian information influence is, targeting a large number of European states. In Eastern Europe, the issue of the refugees has empowered right-wing parties (Bustikova 2019). It is also notable that once a certain narrative is distributed, other regimes and interested actors can pick it up and amplify it. In the ecology of illiberal regimes, some more powerful and some less, certain actors can participate in the production of the propaganda that we identify - and others use it for their advantage, while also passing it along. The mechanism and methods we flag can help others work to delineate a new emerging bloc of political affinities in world affairs (Koesel and Bunce 2013), one that connects political movements of a certain bent across borders. Questions for further research include the relationship between conspiracy narratives and support for authoritarianism, the links between domestic and external propaganda, and what part directed political communication plays in issue- and party-oriented election interventions.

\section{Acknowledgements}

The authors thank the editor and three anonymous reviewers for their help; the usual caveat applies.

\section{Supplemental Materials}

A. Party Political Communication

B. Mass media Data

C. Validation of Sentiment Scores

D. Procedure and Keywords for Similarity to Conspiratorial Language

E. Event Analysis

To view supplementary material for this article, please visit http://doi.org/10.1017/S1537592721003108.

\section{Notes}

1 See https://www.rt.com/news/442769merkel-autocratic-failures-wimmer/.

2 "Die Bundeskanzlerin wusste bestens Bescheid", Willy Wimmer zur Flüchtlingskrise 2015 [DFP 43]", RT September 6, 2019; Wir schaffen das": Statistik nach 5 Jahren", RT August, 31 2020; “Die erste Lüge war das "Wir" - Fünf Jahre Merkels "Wir schaffen das", RT September 29, 2020.

3 "451 Grad |AfD jagt Merkel \& Partner bis Jamaika | 49.5”, RT September 29, 2017; “Die AfD ist eine Art neue Volkspartei der neuen Bundesländer"-Thomas Fasbender im Gespräch”, RT September 29, 2017.

4 For a thorough introduction to the field see Grimmer and Stewart 2013.

5 See Bakalov 2020 for a recent review.

6 See Baum and Potter 2008 on relationship between mass public opinion, media, and foreign policy.

7 Soviet propaganda focused on the failings of capitalism and the ideological superiority of Communism; Ebon 1987.

8 Radio France Internationale and the British Broadcasting Corporation are cases in point.

9 China Global Television Network, the international arm of China Central Television was rebranded in 2016, and can be viewed in this light.

10 A research agenda examines the consequences and behavioral correlates of exposure to conspiracism. Uscinski, Klofostad, and Atkinson 2016 find that conspiratorial disposition appears orthogonal to partisanship in the United States, but belief in conspiracy theories depresses political participation; Uscinski and Parent 2014. Conspiracy is sometimes seen as a populist theory of power; Fenster 2008. Invernizzi and Mohamed 2019 demonstrate experimentally that 
being told that a particular event represents a conspiracy tends to lower trust both in the media, as a source of information, and in official institutions.

11 See "U.S. missiles are big issue in key West German election," 1983, United Press International, March 3; "West Germans Accuse Soviets of Interfering in Election," 1983, Washington Post, February 26; and "Soviets 'Campaign' in Bonn Election, Vigor of Diplomacy Underscores Concerns," February 5.

12 Levin 2020 recounts: "Prior to 2016 there were at least five electoral interventions in American presidential elections using a variety of covert and overt methods by Nazi Germany, Revolutionary France, Great Britain, and the Soviet Union, some using quite similar methods. For example, one of the main methods used by Nazi Germany in their attempt to prevent FDR's election to a third term in the 1940 U.S. elections was the covert leak (via a bribed U.S. newspaper) of a captured Polish government document four days before the election that supposedly showed FDR to be a 'hypocrite' and a 'warmonger'."

13 See European Parliament, 2017, "Asylum and Migration in the EU: Facts and Figures," June 30.

14 Die Linke pursues a leftist agenda, including criticism of capitalism, demands for high levels of redistribution, and a plea for ending Germany's NATO membership. Some highlight its origins as the heir of the state party of German Democratic Republic, and conceive of it as possibly an anti-systemic party.

15 "Alternative für Deutschland AfD-Vize Gauland nennt Flüchtlingskrise 'Geschenk' für seine Partei," 2015, SZ, December 12.

16 Humprecht 2019 also finds that in German-speaking countries, immigrants are most frequently targeted.

17 During Donald Trump's presidency, conspiracies played an important role in mobilizing core political supporters. See Jeff Tollefson, 2021, "Tracking QAnon: How Trump Turned Conspiracy-Theory Research Upside Down," Nature, February 4.

18 Since the FDP was not represented in the Bundestag from 2013-2017, we excluded the FDP from our analysis during this time span. For the AfD, we find a slightly different kind of political communication. The party itself published press releases frequently, especially during the time before 2017 when not being represented in the Bundestag. We use party press releases for the AfD, since they use this tool of political communication on the party level as often as and more importantly following same structure as the parliamentary group from 2017 on.

19 Refer to the online appendix, section A.1, for more, including discussion of the quality of the assembled corpus.

20 We compute the cosine similarity between the vectors representing each article and the topics of the dictionary, and we employ a cut-off on the similarity scores to filter relevant refugee stories, which we combine with the presence of any of the keywords in the title.

21 Total means the sum of positive and negative. We employ WortSchatz, (Remus, Quastoff, and Heyer 2010) with annotated 15,649 positive and 15,632 negative word forms.

22 Like all text-analysis tools, sentiment analysis has its strengths and weaknesses. Its simplicity and tractability makes it a preferred approach in computational social science (Soroka et al. 2015). It cannot capture complex sentiments such as irony, however. Furthermore, the target of the negative sentiments may or may not be what the researcher envisioned.

23 Refer to online appendix section $\mathrm{C}$ for more.

24 NDR.de, 2020, "Verschwörungstheorie: Der große Austausch," March 3 (https://twitter.com/beatrix_ vstorch/status/729267738481430528).

25 https://www.youtube.com/watch?v=YMcReYJrPe4 .

26 PI-news, 2019, "Markus Frohnmaier sieht ernste Bedrohungslage für AfD-Politiker," March 16, and https://www.youtube.com/watch?v=_108c5WQFvs.

27 https://www.youtube.com/watch?v=29trN1IZccU.

28 Der Westen, 2018, "Flüchtlingspakt: AfD-Chef Gauland verbreitet Verschwörungstheorie-danneskaliert es völlig im Bundestag," November 18.

29 "Berlin: Minderjährige vergewaltigt, Polizei tatenlos" 2016, Sputnik, January 17.

30 "In eigener Sache: Die selbsterfüllende Prophezeiung von RT Deutsch als Propagandasender," 2017, RT, September 22.

31 Refer to online appendix, section B, for quality of the corpus.

32 We compute the cosine similarity between the vectors representing each article and the topics of the dictionary, and we employ a cut-off on the similarity scores to filter relevant refugee stories, which we combine with the presence of any of the keywords in the title.

33 For example, Field et al. 2018 analyze " 13 years (100K articles) of the Russian newspaper Izvestia and identify a strategy of distraction: articles mention the U.S. more frequently in the month directly following an economic downturn in Russia."

34 Refer to figure 8 in the online appendix, section C.

35 Refer to online appendix section D.

36 In one conspiracy theory-laced story, RT asks whether Soros is the architect of the plan to resettle refugees in Europe, to weaken the EU, and make it more pliant to its wishes. In others, Merkel and Soros are working together, or there is a left-wing conspiracy to bring more people with Islamic backgrounds to Europe ("War Soros Architekt eines vermeintlichen MerkelPlans zur Destabilisierung Europas?” 2017, see https://deutsch.rt.com/europa/47675- 
Amerkels-geheime-fluechtlingsquoten-ohne-bruesseleu/ in RT Deutsch, March 14). Other stories posit secret deals between Merkel and Erdogan (lhttps:// deutsch.rt.com/europa/47675-merkels-geheimefluechtlingsquoten-ohne-bruessel-eu/), and that global capitalism is to blame (https://deutsch.rt.com/ programme/der-fehlende-part/77539-

kritik-migration-oesterreichischer-historiker-hanneshofbauer-im-gespraech), there is even a conspiracy theory linking the downed MH17 to the refugees (https://deutsch.rt.com/gesellschaft/37041-cnn-undeu-kommission-fluchtlingskrise/).

37 We calculate in a numerical space how close each articles words are to the conspiracy-related topic words; the closer the article to the topic words, the higher the cosine-similarity score.

38 Conspiracy: seventy-fifthth percentile (.11) in German media and fiftieth (.13) in Russian media.

39 Refer to the online appendix, section D.

40 Wagnsson and Barzanje 2021 demonstrate the complexities of conspiratorial narratives, and show that Sputnik supported the Swedish populist right-wing party, the Sweden Democrats, by emphasizing refugees, liberal elites, and identity politics.

41 This data is available at https://ec.europa.eu/eurostat/ data/database, under "Population and Social Conditions ... Asylum and managed migration ... Asylum and Dublin statistics ... Applications, asylum and first-time asylum applicants by citizenship, age and sex, monthly data (rounded)." The Eurostat data source is the German government.

42 See ch. 2, "Suharto, Inc.," in Fisman and Miguel 2008.

43 See Wilf 2016. We thank Meredith Wilf for this specification and help with the approach.

44 Refer to the online appendix, section E.

45 The duration of each event window in days is 59,59 , $59,73,108,80,72$.

46 The model fit, or $\mathrm{R}^{2}$, varies, mostly from .10 to .40 . Ideally, a higher $\mathrm{R}^{2}$ would allow for a more precise estimate in the event window. The wider confidence intervals likely reflect the greater uncertainty associated with the estimation window stage. Full replication code includes fitting the model on events, obtaining a test statistic for the difference between expected and predicted stories; available on request.

47 According to marginals of a survey conducted in March and April 2020, the following percentages of respondents said they used the following media at least one day per week: RT Deutsch, 6.9\%, Sputnik Deutschland, 5.9\%. A sample of 2,233 respondents was drawn from an online access panel of a survey firm using quota sampling designed to match the composition of the German electorate in terms of age, sex, and education. Interviews were conducted from March 17 to April 19, 2020.

48 See Spahn 2018. See also: "Russian disinformation does not only rely on its own resources to spread its narratives about Ukraine. Twitter has been used so heavily that Russia Today and Sputnik are scoring more engagement than some of the German quality media combined"; "Wave of Disinformation from the Azov Sea," 2018, EU DisInfo Review, November 29.

49 See Telepolis, https://www.heise.de/tp/features/ Sputnik-Umfrage-Misstrauen-und-Zweifel-anBerichterstattung-der-Medien-3371430.html.

50 "The AfD had a dispersed network structure of different opinion leaders on Facebook in July 2015. Among the 100,000 to 150,000 monthly active Facebook fans, the official party page had the largest audience with 51,800 . The party leaders Petry and Lucke only had a reach of 12,900 each. Non-party actors had a higher reach within the AfD network, such as the Pegida movement $(32,500)$, or the pro-Russian news outlets Russia Today (RT; 22,400) and Sputnik $(13,400)$, and the Junge Freiheit (JF; 22,100)"; see Jäger 2021, 4.

51 Scholars claim a positive association; Arzheimer and Berning 2019; Mader and Schoen 2019.

52 Though CDU and CSU are separate parties, they act together at the federal level and form a joint parliamentary group.

53 For the case of France and Le Pen see PRI, "Accusations of Russian Meddling Come as No Surprise."

\section{References}

Adena, Maja, Ruben Enikolopov, Maria Petrova,

Veronica Santarosa, and Ekaterina Zhuravskaya. 2015.

"Radio and the Rise of the Nazis in Prewar Germany." Quarterly Journal of Economics 130(4): 1885-939.

Albertazzi, Daiele, and Duncan McDonnell. 2008. TwentyFirst Century Populism. London: Palgrave Macmillan.

Arlt, Dorothee, and Jens Wolling. 2017. "Die

Flüchtlingsdebatte in den Medien aus der Perspektive der Bevölkerung." Media Perspektiven 48(6): 325-37.

Arzheimer, Kai. 2015. "The AfD: Finally a Successful Right-Wing Populist Eurosceptic Party for Germany?” West European Politics 38: 535-56.

Arzheimer, Kai, and Carl Berning. 2019. "How the Alternative for Germany (AfD) and Their Voters Veered to the Radical Right. 2013-2017." Electoral Studies 60: 102040.

Avdagic, Sabrina, and Lee Savage. 2020. "Negativity Bias: The Impact of Framing of Immigration on Welfare State Support in Germany, Sweden and the UK." British Journal of Political Science, 51(2): 624-45.

Bakalov, Ivan. 2020. "Setting Soft Power in Motion: Towards a Dynamic Conceptual Framework." 
European Journal of International Relations 26(2): 495-517.

Baum, Matthew, and Philip Potter. 2008. "The Relationships between Mass Media, Public Opinion, and Foreign Policy: Toward a Theoretical Synthesis." Annual Review of Political Science 11: 39-65.

Bornschier, Simon. 2012. "Why a Right-Wing Populist Party Emerged in France but Not in Germany: Cleavages and Actors in the Formation of a New Cultural Divide." European Political Science Review 4: 121-45.

Bräuninger, Thomas, Marc Debus, Jochen Müller, and Christian Stecker. 2019. "Party Competition and Government Formation in Germany: Business as Usual or New Patterns?" German Politics 28(1): 80-100.

Brutger, Ryan, Stehpen Chaudoin, and Max Kagan 2021. “Trade War or Election Interference?" Presented at GSIPE 2021.

Bubeck, Joannes, and Nikolay Marinov. 2019. Rules and Allies: Foreign Election Interventions. New York: Cambridge University Press.

Bush, Sarah, and Lauren Prather. 2020. "Foreign Meddling and Mass Attitudes towards International Economic Engagement." International Organization 74(3): 584-609.

Bustikova, Lenka. 2019. Extreme Reactions: Radical Right Mobilization in Eastern Europe. New York: Cambridge University Press.

Bustikova, Lenka, David Siroky, Saud Alashri, and Sultan Alzahrani. 2019. "Predicting Partisan Responsiveness: A Probabilistic Text Mining Time-Series Approach.” Political Analysis 28(1): 64.

Butler, Dan, and Ana De La O. 2011. "The Causal Effect of Media-Driven Political Interest on Political Attitudes and Behavior." Quarterly Journal of Political Science 5(4): 321-37.

Corstange, Dan, and Nikolay Marinov. 2012. "Taking Sides in Other People's Elections: The Polarizing Effect of Foreign Intervention." American Journal of Political Science 56(3): 655-70.

Crabtree, Charles, and Holger L. Kern. 2018. "Using Electromagnetic Signal Propagation Models for Radio and Television Broadcasts: An Introduction." Political Analysis 26(3): 348-55.

Cull, Nicholas. 2008. The Cold War and the United States Information Agency: American Propaganda and Public Diplomacy: 1945-1989. New York: Cambridge.

Cushman, Ellery, and Kiril Avramov. 2021. "Eurosodom: Specifics of Weaponized Sexuality and Gender-Based Narratives in Contemporary Russian and Pro-Russian Disinformation." Icono 14 19(1): 123-54.

DellaVigna, Stefano, Ruben Enikolopov, Vera Mironova, Maria Petrova, and Ekaterina Zhuravskaya. 2014.

"Cross-Border Media and Nationalism: Evidence from
Serbian Radio in Croatia." American Economic Journal: Applied Economics 6: 103-32.

Dolezal, Martin. 2008. “Germany: The Dog That Didn't Bark." In West European Politics in the Age of Globalization, ed. Hanspeter Kriesi, Edgar Grande, Romain Lachat, Martin Dolezal, Simon Bornschier, and Timoetheos Frey, 208-233. New York: Cambridge University Press.

Ebon, Martin. 1987. The Soviet Propaganda Machine. New York: McGraw-Hill.

Elswah, Mona, and Philip Howard. 2020. "Anything that Causes Chaos: The Organizational Behavior of Russia Today (RT)." Journal of Communication 70(5): 623-45.

Engesser, Sven, Nicole Ernst, Frank Esser, and Florin Büchel. 2017. "Populism and Social Media: how politicians spread a fragmented ideology." Information, Communication \& Society 20(8): 1109-126.

Fenster, Mark. 2008. Conspiracy Theories: Secrecy and Power in American Culture. Minneapolis: University of Minnesota Press.

Field, Anjalie, Doron Kliger, Shuly Wintner, Jennifer Pan, Dan Jurafsky, and Yulia Tsvetkov. 2018. "Framing and Agenda-Setting in Russian News: A Computational Analysis of Intricate Political Strategies." Conference on Empirical Methods in Natural Language Processing (EMNLP). (https://arxiv.org/pdf/ 1808.09386.pdf).

Fisher, Aleksandr. 2021. "Trickle Down Soft Power: Do Russia's Ties to European Parties Influence Public Opinion?" Foreign Policy Analysis 17(1): oraa013.

Fisman, Raymond, and Edward Miguel. 2008. Economic Gangsters: Corruption, Violence and the Poverty of Nations. Princeton, NJ: Princeton University Press.

Froehlich, Romy, and Burkhard Rüdiger. 2006. "Framing Political Public Relations: Measuring Success of Political Communication Strategies in Germany." Public Relations Review 32(1): 18-25.

Gärtner, Lea, Konstantin Gavras, and Harald Schoen. 2020. "What Tips the Scales? Disentangling the Mechanisms Underlying Post-Electoral Gains and Losses in Democratic Support." Electoral Studies 67: 102210.

Goerres, Achim, Sabrina Mayer, and Dennis Spies. 2020. "Immigrant Voters against Their Wll: A Focus Group Analysis of Identities, Political Issues and Party Allegiances among German Resettlers during the 2017 Bundestag Election Campaign." Journal of Ethnic and Migration Studies 46(7): 1205-22.

Goldsmith, Benjamin E., and Yusaku Horiuchi. 2009. "Spinning the Globe? U.S. Public Diplomacy and Foreign Public Opinion.” Journal of Politics 71: 863-75. Golova, Tatiana. 2020. "Post-Soviet Migrants in Germany, Transnational Public Spheres and Russian 
Soft Power." Journal of Information Technology \& Politics 17(3): 249-67.

Grimm, Robert. 2015. "The Rise of the German Eurosceptic Party Alternative Für Deutschland: Between Ordoliberal Critique and Popular Anxiety." International Political Science Review 36: 264-78.

Grimmer, Justin, and Brandon Stewart. 2013. "Text as Data: The Promise and Pitfalls of Automatic Content Analysis Methods for Political Texts." Political Analysis 21(3): 267-97.

Gunitsky, Sava. 2015. "Corrupting the Cyber-Commons: Social Media as a Tool of Autocratic Stability."

Perspectives on Politics 13(1): 42-54.

Harris, Paul. 2001. "Imagined Identity: Immigration, Ueberfremdung, and Cultural Chauvinism in German Far-Right Partisan Discourse." German Policy Studies 1(3): 331-58.

Hawkins, Kirk. 2009. "Is Chavez Populist? Measuring Populist Discourse in Comparative Perspective." Comparative Political Studies 42(8): 1040-67.

Hetherington, Marc, and Jonathan Weiler. 2009. Authoritarianism and Domination in American Politics. New York: Cambridge University Press.

Hooghe, Liesbet, and Gary Marks. 2018. "Cleavage Theory Meets Europe's Crises: Lipset, Rokkan, and the Transnational Cleavage." Journal of European Public Policy 25(1): 109-35.

Humprecht, Edda. 2019. "Where 'Fake News' Flourishes: A Comparison across Four Western Democracies." Information, Communication \& Society 22(13): 1973-88.

Hyde, Susan. 2011. The Pseudo-Democrats Dilemma: Why Election Observation Became an International Norm. Ithaca, NY: Cornell University Press.

Invernizzi, Giovanna, and Ahmed Mohamed. 2019. "Trust Nobody: How Conspiracy Theories Can Distort Political Acocuntability." Available at SSRN. (https:// papers.ssrn.com $/$ sol3/papers.cfm?abstract_id= 3507190).

Johnson, Robert. 2018. "Hybrid War and Its Countermeasures: A Critique of the Literature." Small Wars and Insurgencies 29(1): 141-63.

Jäger, Kai. 2021. "When Do Party Supporters Abandon the Party Leader? The Intraparty Conflict of the Alternative for Germany." Party Politics 27(3): 478-88.

Kahle, Brewster. 1997. "Preserving the Internet." Scientific American 276(3): 82-83.

Kim, Sung Eun, and Yotam Margalit. 2021. "Tariffs as Electoral Weapons: The Political Geography of the US-China Trade War." International Organization 75(1): 1-38.

Koesel, Karrie, and Valerie Bunce. 2013. "DiffusionProofing: Russian and Chinese Responses to Waves of Popular Mobilizations against Authoritarian Rulers." Perspectives on Politics 11(3): 753-68.
Kriesi, Hanspeter, Edgar Grande, Romain Lachat, Martin Dolezal, Simon Bornschier, and Timotheos Frey. 2006. "Globalization and the Transformation of the National Political Space: Six European Countries Compared." European Journal of Political Research 45(6): 921-56.

Lasswell, Harald. 1938. Propaganda Technique in the World War. New York: Peter Smith.

Levin, Dov. 2016. "When the Great Power Gets a Vote: The Effects of Great Power Electoral Interventions on Election Results." International Studies Quarterly 60(2): 189-202.

- 2020. Meddling in the Ballot Box: The Causes and Effects of Partisan Electoral Interventions. New York: Oxford University Press.

Machain, Carla. 2021. "Exporting Influence: U.S.Military Training as Soft Power." Journal of Conflict Resolution 65(2-3): 313-41.

MacKinlay, A. Craig. 1997. "Event Studies in Economics and Finance." Journal of Economic Literature 35(1): 13-39.

Mader, Matthias, and Harald Schoen. 2019. "The European Refugee Crisis, Party Competition, and Voters' Responses in Germany." West European Politics 42(1): 67-90.

Manning, Christopher, Prabhakar Raghavan, and Hinrich Schütze. 2008. Introduction to Information Retrieval. New York: Cambridge University Press.

Marinov, Nikolay, and Maria Popova. 2021. "Will the Real Conspiracy Please Stand Up: Sources of PostCommunist Democratic Failure." Perspectives on Politics. doi:10.1017/S1537592721001973

Mikolov, Tomas, Ilya Sutskever, Kai Chen, Greg Corrado, and Jeffrey Dean. 2013. "Distributed Representations of Words and Phrases and Their Compositionality." In Advances in Neural Information Processing Systems, 3111-19.

Moffitt, Benjamin. 2016. The Global Rise of Populism: Performance, Political Style, and Representation.

Stanford: Stanford University Press.

Molz, Günther, and Michael Stiller. 2019. "Attitudes and Opinions about Refugees in Germany-Correlates with Conspiracy and Political Mindsets." Current Psychology 40: 2201-10.

Mudde, Cas. 2007. Populist Radical Right Parties in Europe. New York: Cambridge University Press.

- 2004. "The Populist Zeitgeist." Government and Opposition 39(4): 541-63.

Norris, Pippa, and Ron Inglehart. 2019. Cultural Backlash: Trump, Brexit and Authoritarian Populism. New York: Cambridge University Press.

Nye, Joseph, Jr. 1984. The Making of America's Soviet Policy. New Haven, CT: Yale University Press.

Pomerantsev, Peter, and Michael Weiss. 2014. "The Menace of Unreality: How the Kremlin Weaponizes 
Information, Culture and Money.” Report. New York: Institute of Modern Russia.

Ramsay, Gordon, and Sam Robertshaw. 2019.

"Weaponising News: RT, Sputnik and Targeted

Disinformation." Report, Policy Institute Center for the Study of Media, Communication and Power. London: Kings College.

Remus, Robert, Uwe Quasthoff, and Gerhard Heyer. 2010. "Sentiws: A Publicly Available GermanLanguage Resource for Sentiment Analysis." Proceedings of the 7th International Language Resources and Evaluation (LREC'10): 1168-71.

Robertson, Graeme. 2017. "Political Orientation, Information and Perceptions of Election Fraud: Evidence from Russia." British Journal of Political Science 47(3): 589-608.

Rone, Julia. 2021. "Far Right Alternative News Media as 'Indignation Mobilization Mechanisms': How the Far Right Opposed the Global Compact for Migration." Information, Communication \& Society. https:// doi.org/10.1080/1369118X.2020.1864001

Rooduijn, Matthijs, and Teun Pauwels. 2011. "Measuring Populism: Comparing Two Methods of Content Analysis." West European Politics 34(6): 1272-83.

Rooduijn, Matthijs, Stujn van Kessel, Caterina Froio, Andrea Pirro, Sarah De Lange, Daphne Halikiopoulou, Paul Lewis, Cas Mudde, and Paul Taggart. 2019. "The Populist: An Overview of Populist, Far Right, Far Left and Eurosceptic Parties in Europe." (https:// populist.org/, accessed on 09/01/2021).

Rosellini, Julian. 2020. The German New Right: AfD, PEGIDA and the Re-Imagining of National Identity. Oxford: Oxford University Press.

Sanovich, Sergey, Denis Stukal, and Joshua Tucker. 2021. "Turning the Virtual Tables: Government Strategies for Addressing Online Opposition with an Application to Russia." Comparative Politics 50(3): 435-54.

Šaric, Frane, Goran Glavaš, Mladen Karan, Jan Šnajder, and Bojana Bašic. 2012. "Takelab: Systems for Measuring Semantic Text Similarity." In Proceedings of the First Joint Conference on Lexical and Computational Semantics-Volume 1: Proceedings of the Main Conference and the Shared Task, and Volume 2: Proceedings of the Sixth International Workshop on Semantic Evaluation, 441-448. Association for Computational Linguistics.

Sartori, Giovanni. 1976. Parties and Party Systems: A Framework for Analysis. New York: Cambridge University Press.

Schaub, Max, and Davide Morisi. 2020. "Voter Mobilisation in the Echo Chamber: Broadband
Internet and the Rise of Populism in Europe." European Journal of Political Research 59(4): 752-73.

Schmitt-Beck, Rüdiger. 2017. "The 'Alternative für Deutschland in the Electorate': Between Single-Issue and Right-Wing Populist Party." German Politics 26(1): 124-48.

Shulman, Stephen, and Stephen Bloom. 2012. "The Legitimacy of Foreign Intervention in Elections: The Ukrainian Response." Review of International Studies 38(4): 445-71.

Slominski, Peter, and F. Trauner. 2018. "How Do Member States Return Unwanted Migrants? The Strategic (Non-)Use of 'Europe' during the Migration Crisis." Journal of Common Market Studies 56(1): 101-18.

Soroka, Stuart, Lori Young, and Meital. Balmas. 2015. "Bad News or Mad News? Sentiment Scoring of Negativity, Fear, and Anger in News Content." Annals of the American Academy of Political and Social Science 659: 108-21.

Spahn, Susanne. 2018. "Russische Medien in Deutschland: Unabhaengiger Journalismus oder politisches Instrument?” Friedrich-Naumann-Stiftung fuer die Freiheit.

Svolik, Milan. 2013. "Learning to Love Democracy: Electoral Accountability and the Success of Democracy." American Journal of Political Science 57(3): 685-702.

Tomz, Michael, and Jessica Weeks. 2020. "Public Opinion and Foreign Electoral Intervention." American Political Science Review 114(3): 1-18.

Uscinski, Joseph, Casey Klofstad, and Matthew Atkinson. 2016. "What Drives Conspiratorial Beliefs? The Role of Informational Cues and Predispositions." Political Research Quarterly 69(1): 57-71.

Uscinski, Joseph, and Joseph Parent. 2014. American Conspiracy Theories. Oxford: Oxford University Press. von Borzyskowski, Inken. 2019. The Credibility Challenge: How Democracy Aid Influences Election Violence. Ithaca, NY: Cornell University Press.

Wagnsson, Charlotte, and Costan Barzanje. 2021. "A Framework for Analysing Antagonistic Narrative Strategies: A Russian Tale of Swedish Decline." Media, War \& Conflict 14(2): 239-57.

Wilf, Meridith. 2016. "Credibility and Distributional Effects of International Banking Regulations: Evidence from US Bank Stock Returns.” International Organization 70(4): 763-96.

Wood, Steve. 2020. “'Understanding' for Russia in Germany: International Triangle Meets Domestic Politics." Cambridge Review of International Affairs. https://doi.org/10.1080/09557571.2019.1703647 